\title{
Analisis Pertumbuhan Beberapa Varietas Kedelai pada Perbedaan Intensitas Cekaman Kekeringan
}

\section{Growth Analysis of Some Soybean Varieties Under Different Drought Stress Intensity}

\author{
Ratih Suryaningrum ${ }^{1)}$, Edi Purwanto ${ }^{2)}$, Sumiyati ${ }^{2)}$
}

\begin{abstract}
Soybean demand in the market today has not been matched by domestic production. Many of the problems that cause insufficient production of soy, one of which is the drought affecting soybean growth and yield. Efforts should be made to overcome the drought is to provide soybean varieties tolerant to drought stress. This study aims to assess the effect of the difference in intensity of drought stress on the growth of some soybean varieties. This study uses a completely randomized design (CRD) factorial with two factors, the first factor and the second factor soybean varieties drought stress levels. Results showed significant of lowering the value of RGR and NAR. The higher the level of drought stress will decrease soybean growth. Tolerance limits for each variety is at $80 \%$ moisture content.
\end{abstract}

Keywords : soybean, growth, stress

\section{PENDAHULUAN}

Peningkatan permintaan kedelai dipasaran harus diimbangi dengan peningkatan produksi dalam negeri. Namun produksi kedelai saat ini belum dapat memenuhi kebutuhan pasar nasional walaupun terjadi peningkatan produksi dari tahun 2014 sampai 2015. Kurangnya produksi kedelai nasional karena penanaman yang tidak sesuai dengan musimnya, dimana umumnya kedelai ditanam pada musim kemarau di lahan sawah sedangkan pada musim hujan di lahan kering. Hal ini akan mempengaruhi pertumbuhan dan hasil tanaman karena akan ditemui beberapa kendala diantaranya adalah ketersediaan air yang tidak sesuai dengan kebutuhan tanaman. Kondisi kekurangan air atau cekaman kekeringan akan menjadi kendala utama dalam upaya peningkatan produksi tanaman jika penyediaan air melalui sistem irigasi tidak tersedia mengingat kedelai lebih sensitif terhadap kekeringan daripada jenis kacang yang lain.

Pengaruh langsung dari cekaman kekeringan adalah dapat meyebabkan penurunanan turgor tanaman. Sedangkan secara tidak langsung berpengaruh terhadap proses fisiologis seperti fotosintesis, metabolisme nitrogen, absorbsi hara dan translokasi fotosintat (Salisbury dan Ross 1985). Apabila berlangsung pada periode yang lama akan berdampak kematian pada tanaman. Upaya untuk mengatasi masalah cekaman kekeringan dalam budidaya kedelai dapat didukung dengan menyediakan varietas kedelai yang toleran terhadap cekaman kekeringan. Berdasarkan uraian diatas maka perlu dilakukan penelitian ini untuk mengetahui bagaimana pertumbuhan dan batas tingkat toleransi

\footnotetext{
${ }^{1)}$ Undergraduated student of Study Program of Agrotechnology, Faculty of Agrculture the University of Sebelas Maret (UNS) in Surakarta.

${ }^{2)}$ Lecturer Staff at Study Program of Agrotechnology, Faculty of Agrculture the University of Sebelas Maret (UNS) in Surakarta.
}

Contact Author: edipur_uns@yahoo.com pada beberapa varietas pada tingkat cekaman yang berbeda.

\section{METODE PENELITIAN}

Penelitian ini dilaksanakan pada bulan April-Juni 2015 dan bertempat di Laboratorium Kimia Tanah, Jumantono dan Laboratorium Ekologi Manajemen dan Produksi Tanaman (EMPT) Fakultas Pertanian UNS. Adapun peralatan yang digunakan meliputi polibag (35 cm x $35 \mathrm{~cm}$ ), oven, timbangan analitik, alat ukur dan alat pendukung lainnya. Bahan yang digunakan dalam penelitian ini adalah tanah, benih kedelai varietas Burangrang, Wilis, dan Anjasmoro.

Penelitian ini menggunakan Rancangan Acak Lengkap (RAL) yang disusun secara faktorial dengan dua faktor, yaitu varietas kedelai $(\mathrm{V})$ terdiri atas tiga taraf, varietas Burangrang $\left(\mathrm{V}_{1}\right)$, varietasWilis $\left(\mathrm{V}_{2}\right)$, dan varietas Anjasmoro $\left(\mathrm{V}_{3}\right)$. Faktor kedua kadar lengas (K) terdiri atas empat taraf yaitu kadar lengas $100 \%$ $\left(\mathrm{K}_{0}\right)$, kadar lengas $80 \%\left(\mathrm{~K}_{1}\right)$, kadar lengas $60 \%\left(\mathrm{~K}_{2}\right)$ dan kadar lengas $40 \%\left(K_{3}\right)$. Sehingga didapatkan 12 kombinasi perlakuan dimana setiap perlakuan diulang sebanyak 3 kali sehingga didapat 36 unit percobaan. Data dianalisis dengan analisis keragaman atau Analysis of Varian (Anova), apabila terdapat perbedaan yang nyata dilanjutkan dengan uji DMRT pada taraf $5 \%$. Variabel pengamatan meliputi berat kering total, Luas Daun Spesifik, Indeks Luas Daun, Laju Pertumbuhan Relatif dan Laju Asimilasi Bersih.

\section{HASIL DAN PEMBAHASAN}

\section{Berat Kering Total}

Berat kering tanaman mencerminkan akumulasi senyawa organik yang berhasil disintesis tanaman dari senyawa anorganik, terutama air dan karbondioksida. Unsur hara yang telah diserap akar memberi kontribusi terhadap pertambahan berat kering tanaman. Hasil analisis sidik ragam menunjukan bahwa perlakuan tidak berpengaruh nyata terhadap tanaman hanya pada umur 37 HST, sedangkan pada umur 44, 51 dan 58 HST. 


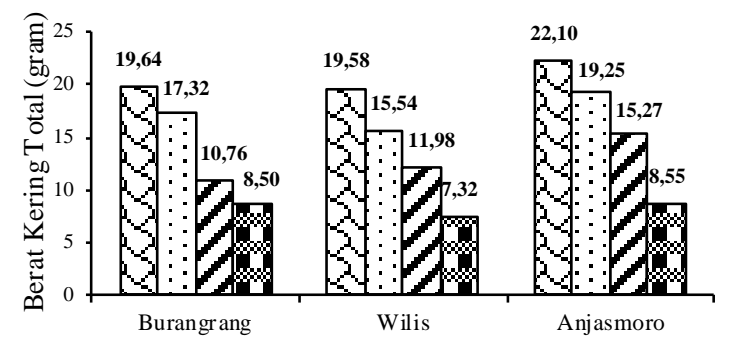

$\square 100 \% \square 80 \% \quad \square 60 \% \quad \mathbf{4 0 5}$

Gambar 1. Histogram pengaruh cekaman kekeringan terhadap berat kering total beberapa varietas kedelai

Berdasarkan Gambar 1, dapat diketahui bahwa dari ketiga varietas diatas, varietas Anjasmoro mempunyai hasil yang terbaik disetiap perlakuan yang diberikan dibandingkan dengan varietas yang lainnya dimana untuk hasil berat kering total tertinggi ditunjukan oleh varietas Anjasmoro yaitu sebesar $22,10 \mathrm{~g}$ pada kadar lengas $100 \%$, masih pada tingkat cekaman yang sama hasil berat kering total disusul oleh varietas Burangrang dan Wilis yang tidak jauh berbeda, yaitu 19,64 g dan 19,58 g. Sedangkan untuk hasil terendah dimiliki oleh varietas Wilis pada kadar lengas $40 \%$ sebesar 7,32 g. Semua varietas menunjukkan bahwa ketika diberi cekaman kekeringan pada tingkat yang lebih tinggi akan menunjukkan hasil berat kering total yang semakin menurun. Hal ini sesuai dengan petanyaan dari Wawan (2006), bahwa potensi hasil biji kedelai dilapangan masih dipengaruhi oleh interaksi antara faktor genetik, varietas dengan pengelolaan kondisi lingkungan tumbuh. Bila pengelolaan lingkungan tumbuh tidak dilakukan dengan baik, potensi daya hasil biji yang tinggi dari varietas yang unggul tersebut tidak tercapai.

\section{Luas Daun Spesifik}

Luas daun spesifik (LDS) merupakan nisbah luas daun dan bobot daun tanaman. Nilai LDS menggambarkan efisiensi daun untuk membentuk bobot kering daun dan memberikan petunjuk tentang tebal tipisnya daun tanaman akibat pengaruh lingkungan (Kadekoh 2002). Berdasarkan analisis ragam luas daun spesifik, perlakuan yang diberikan tidak berpengaruh nyata terhadap tanaman kedelai pada umur 37 HST, 44 HST dan 51 HST. Namun perlakuan berpengaruh nyata pada tanaman berumur 58 HST tetapi tidak terjadi interaksi antar kedua perlakuan.

Tabel 1 menunjukan bahwa adanya peningkatan dan penurunan pada tanaman pada semua varietas. Kenaikan mulai ditunjukan pada awal pertumbuhan sampai dengan peningkatan luas daun spesifik yang cukup besar. Rata-rata peningkatan luas daun spesifik terbesar terjadi pada varietas Wilis sedangkan terendah dimiliki oleh Anjasmoro. Namun setelah terjadi peningkatan tersebut diikuti penurunan luas daun spesifik seiring dengan bertambahnya umur tanaman. Penurunan yang terjadi dapat dikatakan besar, dimana varietas mengalami penurunan antara $52-132 \mathrm{~cm}^{2} \mathrm{~g}^{-1}$.

Pada pengamatan akhir, varietas Anjasmoro memiliki nilai LDS tertinggi pada semua perlakuan yaitu kadar lengas $100 \%, 80 \%, 60 \%$ dan $40 \%$ berturut-turut sebesar 130,916 $\mathrm{cm}^{2} \mathrm{~g}^{-1}, 105,61 \mathrm{~cm}^{2} \mathrm{~g}^{-}$ , $96,94 \mathrm{~cm}^{2} \mathrm{~g}^{-1}$ dan $92,56 \mathrm{~cm}^{2} \mathrm{~g}^{-1}$. Sedangkan nilai LDS terendah oleh varietas Wilis yaitu sebesar 105,98 $\mathrm{cm}^{2} \mathrm{~g}^{-1}$ pada tingkat cekaman $100 \%, 101,72 \mathrm{~cm}^{2} \mathrm{~g}^{-1}$ pada kadar lengas $80 \%, 94,94 \mathrm{~cm}^{2} \mathrm{~g}^{-1}$ pada kadar lengas $60 \%$ dan $88,93 \mathrm{~cm}^{2} \mathrm{~g}^{-1}$ pada kadar lengas $40 \%$. Varietas Wilis diawal pertumbuhan mempunyai nilai LDS yang tinggi namun seiring dengan bertambahnya tingkat cekaman yang diberikan justru mengalami penurunan.

Tabel 1. Pengaruh tingkat cekaman kekeringan terhadap luas daun spesifik pada beberapa varietas kedelai

\begin{tabular}{llllll}
\hline \multirow{2}{*}{ Varietas } & \multirow{2}{*}{ Kadar Lengas (\%) } & \multicolumn{4}{c}{ Luas Daun Spesifik $\left(\mathrm{cm}^{2} \mathrm{~g}^{-1}\right)$} \\
\cline { 3 - 6 } Burangrang & $37 \mathrm{HST}$ & $44 \mathrm{HST}$ & $51 \mathrm{HST}$ & $58 \mathrm{HST}$ \\
& 100 & 117,7 & 206,07 & 73,13 & $107,93 \mathrm{a}$ \\
& 80 & 94,95 & 136,16 & 67,50 & $95,49 \mathrm{a}$ \\
& 60 & 93,09 & 155,50 & 67,41 & $88,93 \mathrm{ab}$ \\
\multirow{3}{*}{ Wilis } & 40 & 106,97 & 121,28 & 55,20 & $92,08 \mathrm{~b}$ \\
& 100 & 134,21 & 127,05 & 47,46 & $105,98 \mathrm{a}$ \\
& 60 & 101,43 & 120,38 & 49,40 & $101,72 \mathrm{a}$ \\
& 40 & 105,89 & 119,60 & 44,57 & $94,94 \mathrm{ab}$ \\
\multirow{3}{*}{ Anjasmoro } & 100 & 90,80 & 115,43 & 52,64 & $88,93 \mathrm{~b}$ \\
& 60 & 118,56 & 190,39 & 106,97 & $130,916 \mathrm{a}$ \\
& 40 & 185,06 & 191,60 & 82,72 & $105,61 \mathrm{a}$ \\
\hline
\end{tabular}

Keterangan: Angka yang diikuti oleh huruf yang sama pada kolom yang sama menunjukkan tidak berbeda nyata pada taraf $5 \%$ DMRT .

\section{Indeks Luas Daun}

Sitompul dan Guritno (1995) menyatakan bahwa indeks luas daun merupakan perbandingan luas daun total dengan luas tanah yang ditutupi atau luas daun diatas suatu luasan tanah.Berdasarkan analisis ragam indeks luas daun, perlakuan cekaman kekeringan yang diberikan tidak berpengaruh nyata terhadap tanaman kedelai pada umur $37 \mathrm{HST}, 44$ HST dan 51 
HST. Sedangkan pada tanaman berumur 58 HST pelakuan menunjukan pengaruh yang nyata terhadap tanaman kedelai namun tidak terjadi interaksi antar kedua perlakuan.

Tabel 2. Pengaruh tingkat cekaman kekeringan terhadap indeks luas daun pada beberapa varietas kedelai

\begin{tabular}{|c|c|c|c|c|c|}
\hline \multirow{2}{*}{ Varietas } & \multirow{2}{*}{ Kadar Lengas (\%) } & \multicolumn{4}{|c|}{ Indeks Luas Daun $\left(\mathrm{cm}^{2} / \mathrm{cm}^{2}\right)$} \\
\hline & & $37 \mathrm{HST}$ & $44 \mathrm{HST}$ & $51 \mathrm{HST}$ & $58 \mathrm{HST}$ \\
\hline \multirow{4}{*}{ Burangrang } & 100 & 0,037 & 0,090 & 0,060 & $0,116 a b$ \\
\hline & 80 & 0,035 & 0,097 & 0,058 & $0,127 a b$ \\
\hline & 60 & 0,033 & 0,068 & 0,044 & 0,070 a \\
\hline & 40 & 0,036 & 0,066 & 0,043 & $0,072 \mathrm{a}$ \\
\hline \multirow{4}{*}{ Wilis } & 100 & 0,041 & 0,086 & 0,047 & $0,110 \mathrm{ab}$ \\
\hline & 80 & 0,033 & 0,080 & 0,049 & $0,101 \mathrm{ab}$ \\
\hline & 60 & 0,089 & 0,077 & 0,037 & $0,0634 a$ \\
\hline & 40 & 0,039 & 0,058 & 0,031 & 0,049 a \\
\hline \multirow{4}{*}{ Anjasmoro } & 100 & 0,038 & 0,104 & 0,055 & $0,131 \mathrm{ab}$ \\
\hline & 80 & 0,045 & 0,085 & 0,066 & $0,110 a b$ \\
\hline & 60 & 0,047 & 0,085 & 0,052 & 0,072 a \\
\hline & 40 & 0,045 & 0,062 & 0,053 & 0,071 a \\
\hline
\end{tabular}

Keterangan: Angka yang diikuti oleh huruf yang sama pada kolom yang sama menunjukkan tidak berbeda nyata pada taraf $5 \%$ DMRT.

Tabel diatas menunjukan bahwa perlakuan mulai berpengaruh nayata pada umur 58 HST.Sama halnya dengan sebelumnya, indeks luas daun juga mengalami peningkatan dan penurunan seperti pada luas daun spesifik. Untuk nilai indeks luas daun tertinggi pada umur 58 HST ditunjukan oleh varietas Anjasmoro pada kadar lengas $100 \%$ dan nilai terendah ditunjukan oleh varietas Wilis pada kadar lengas $40 \%$. Sehingga dapat dikatakan bahwa indeks luas daun semakin menurun seiring tingginya tingkat cekaman dan bertambahnya umur tanaman. Fitter dan Hay (1999) menyatakan bahwa air merupakan komponen utama untuk pertumbuhan tanaman mengingat $70-90 \%$ bagian tumbuhan mengandung air. Apabila pada periode kritis dimana tanaman memerlukan air dalam jumlah tertentu pada fase pertumbuhannya, namun kebutuhan air tidak terpenuhi maka tanaman akan mengalami cekaman kekeringan.

\section{Laju Pertumbuhan Relatif}

Asumsi yang digunakan untuk persamaan kuantitatif LPR adalah bahwa pertambahan biomassa tanaman per satuan waktu tidak konstan tetapi tergantung pada berat awal tanaman (Sitompul dan Guritno 1995). Berdasarkan hasil analisis sidik ragam, diketahui bahwa perlakuan yang diberikan tidak berpengaruh nyata pada laju pertumbuhan relatif tanaman kedelai pada umur 37 sampai 51 HST. Perlakuan mulai berpengaruh nyata pada umur 51-58 HST serta terjadi interaksi antar perlakuan. Hal ini dapat ditunjukan pada grafik hasil laju pertumbuhan (LPR) (Gambar 2).

Berdasarkan gambar diatas, dapat diketahui kenaikan nilai LPR pada awal pertumbuhan namun diakhir pertumbuhan terjadi penurunan pada semua varietas. Penurunan pada verietas Burangrang adalah sebesar $0,024 \mathrm{~g} / \mathrm{g} / \mathrm{hari}$ pada kadar lengas $100 \%$ sedangkan pada tingkat cekaman $80 \%$ sebesar 0,11 g $\mathrm{g}^{-1}$ hari $^{-1}$, untuk kadar lengas $60 \%$ dan $40 \%$ penurunan nilai LPR nya adalah sebesar 0,020 $\mathrm{g} / \mathrm{g} / \mathrm{hari}$ dan $0,067 \mathrm{~g} \mathrm{~g}^{-1}$ hari $^{-1}$. Varietas Wilis dengan kadar lengas $100 \%$ mengalami penurunan sebesar $0,113 \mathrm{~g} \mathrm{~g}^{-1}$ hari $^{-1}$, sedangkan pada kadar lengas $80 \%$ terjadi sedikit peningkatan sebesar $0,011 \mathrm{~g} / \mathrm{g} / \mathrm{hari}$ dan pada kadar lengas $60 \%$ dan $40 \%$ sebesar 0,108 $\mathrm{g} /$ hari dan $0,107 \mathrm{~g} \mathrm{~g}^{-1}$ hari $^{-1}$. Sementara itu untuk penurunan nila $L A B$ pada varietas Anjasmoro dengan kadar lengas $100 \%, 80 \%$ dan $60 \%$ berturut turut dalah sebesar $0,027 \mathrm{~g} \mathrm{~g}^{-1}$ hari ${ }^{-1}, 0,065 \mathrm{~g} \mathrm{~g}^{-1}$ hari ${ }^{-1}$ dan $0,040 \mathrm{~g}$ $\mathrm{g}^{-1} \mathrm{hari}^{-1}$, sedikit peningkatan terjadi pada kadar lengas $40 \%$ sebesar $0,011 \mathrm{~g} \mathrm{~g}^{-1}$ hari $^{-1}$.

Nilai LPR semakin menurun seiring dengan bertambah tingginya tingkat perlakuan dan umur tanaman tersebut. Hal ini sesuai dengan pernyataan (Islami 1995), bahwa tertekannya pertumbuhan tanaman sebagai akibat kekurangan air terlihat dari menurunnya laju pertumbuhan tanaman dan laju pertumbuhan relatif sebagai akibat dari menurunnya efisiensi fotosintesis, yang terlihat dari berkurangnya laju asimilasi netto.

\section{Laju Asimilasi Bersih}

Laju asimilasi bersih merupakan ukuran rata-rata efisiensi fotosintesis daun dalam suatu komunitas tanaman budidaya (Gardner et al. 1991). Berdasarkan hasil analisis ragam, diketahui bahwa perlakuan tidak berpengaruh nyata terhadap laju asimilasi bersih tanaman kedelai pada umur 37 sampai 51 HST, namun perlakuan berpengaruh nyata pada umur 5158 HST. Hal ini dapat ditunjukkan pada grafik hasil laju asimilasi bersih pada Gambar 3. 

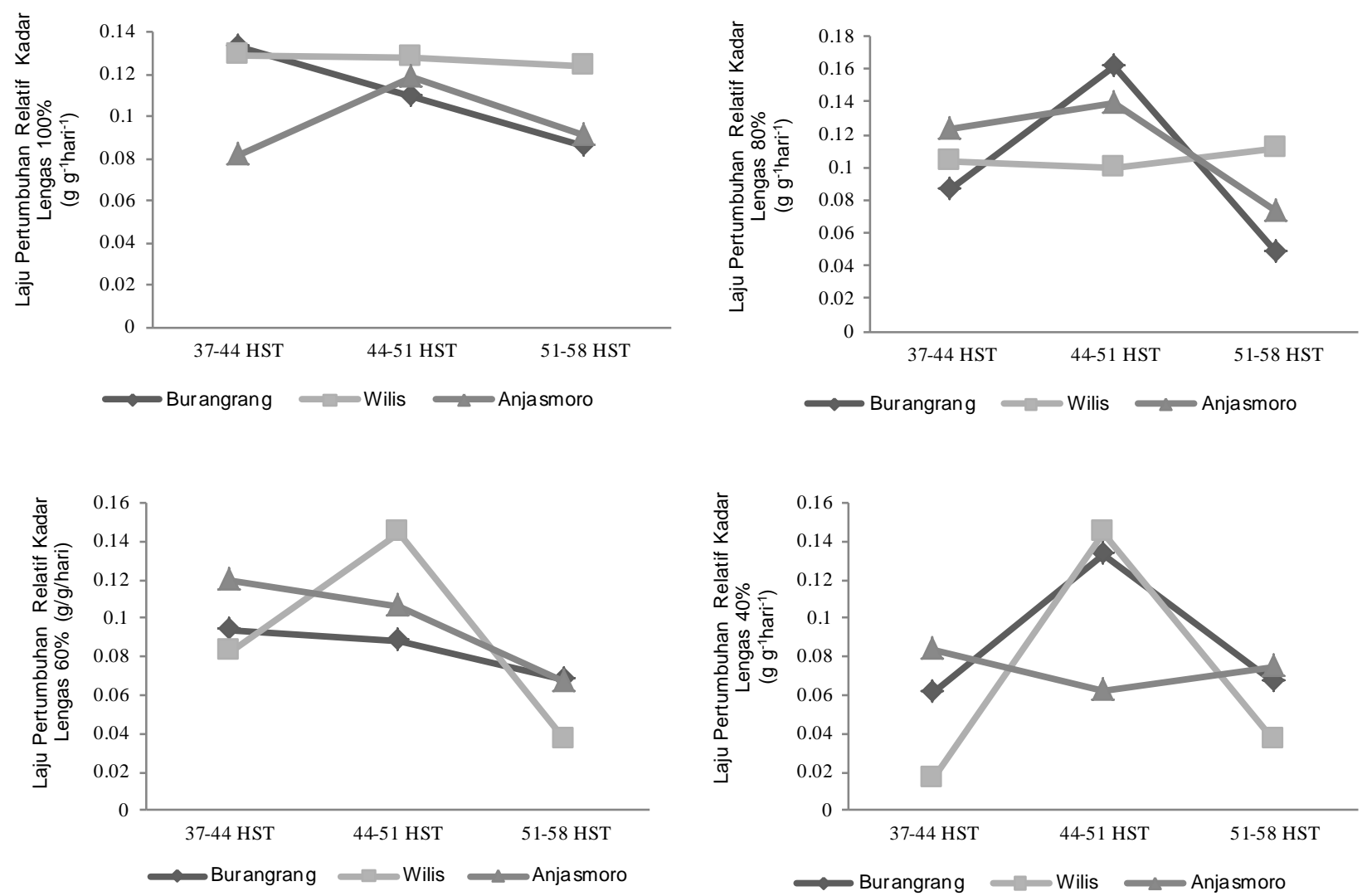

Gambar 2. Grafik pengaruh cekaman kekeringan terhadap laju pertumbuhan relatif (LPR) pada beberapa vaeritas kedelai

Bedasarkan grafik diatas dapat diketahui bahwa pada kadar lengas 100\%, laju asimilasi bersih mengalami kenaikan yang saling beriiringan dan tidak jauh berbeda. Rata-rata kenaikan nilai LAB yang terjadi pada kadar lengas $100 \%$ sebesar 0,0038 $\mathrm{g} / \mathrm{cm}^{2} /$ hari, kenaikan terjadi seiring dengan bertambahnya umur tanaman. Hal ini karena kebutuhan air yang diberikancukup dan dapat digunakan oleh tanaman untuk proses fotosintesis.

Semua varietas pada kadar lengas 80,60 dan $40 \%$ mulai mengalami penurunan seiring dengan bertambahnya umur tanaman. Penurunan nilai LAB ini disebabkan oleh semakin berkurangnya kebutuhan air oleh tanaman, sehingga proses fotosintesis berkurang. Sementara itu Yasemin (2005) menyatakan bahwa selama terjadi cekaman kekeringan terjadi penurunan laju fotosintesis yang disebabkan oleh penutupan stomata danterjadinya penurunan transport elektron dan kapasitas fosforilasi didalam kloroplas daun. Seperti sebelumnya, hasil pengamatan LAB menunjukan varietas Anjasmoro memiliki toleransi yang baik dibandingkan dengan varietas yang lain. Hal ini ditunjukan oleh besarnya nilai $L A B$ yaitu sebesar $0,0083 \mathrm{~g} \mathrm{~cm}^{-2}$ hari ${ }^{-1}$ pada kadar lengas $40 \%$ di umur 51-58 HST. Disusul oleh varietas Burangang yang memiliki nilai $L A B$ sebesar
$0,0076 \mathrm{~g} \mathrm{~cm}^{-2}$ hari ${ }^{-1}$ dan terendah oleh varietas Wilis sebesar $0,0059 \mathrm{~g} \mathrm{~cm}^{-2}$ hari ${ }^{-1}$.

\section{KESIMPULAN DAN SARAN \\ Kesimpulan}

Berdasarkan penelitian yang telah dilaksanakan, maka dapat disimpulkan bahwa :

1. Cekaman kekeringan berpengaruh nyata terhadap LPR dan LAB, dimana semakin tinggi tingkat cekaman maka akan menurunkan pertumbuhan kedelai, namun varietas yang diujikan masih toleran pada tingkat kadar lengas $80 \%$.

2. Toleransi terbaik pada tingkat kadar lengas $40 \%$ adalah varietas Anjasmoro dan varietas Wilis mempunyai toleransi rendah.

\section{Saran}

Saran yang dapat disampaikan untuk penelitian ini adalah perlu adanya pernambahan alat penelitian yaitu alas untuk menampung air, serta perlu adanya penelitian yang lebih lanjut mengenai dampak cekaman kekeringan secara langsung dilapang dengan tingkat cekaman kekeringan yang sama. 

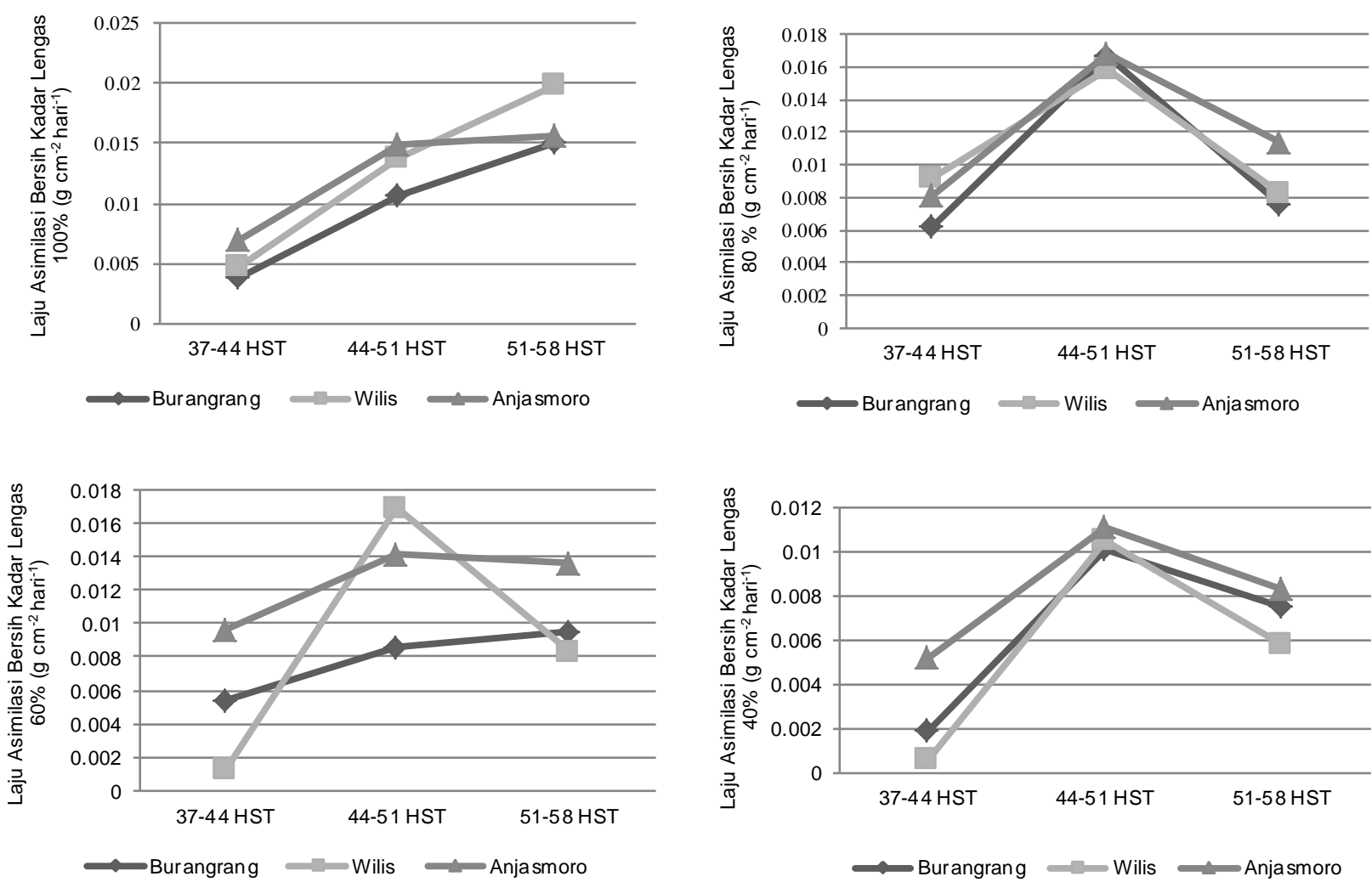

Gambar 3. Grafik pengaruh cekaman kekeringan terhadap laju asimilasi bersih (LAB) pada beberapa varietas kedelai

\section{DAFTAR PUSTAKA}

Fitter AH, Hay, Rkk. 1999. Fisiologi lingkungan tanaman. Yogyakarta (ID): UGM.

Gardner FP, Pearce RB, Mitchell RL. 1991. Fisiologi tanaman budidaya. Yogyakarta (ID): Gadjah Mada Press.

Kadekoh I. 2002. Pola pertumbuhan kacang tanah (Arachis hipogaea L.) dengan jarak tanam bervariasi dalam sistem tumpangsari dengan jagung pada musim kemarau. J Agrista 6(1): 6370.

Salisbury FB, Ross CW. 1985. Plant physiology. Third Edition. Wadworth Publishing Company Inc., Belmont, California. 540p.
Sitompul SM, Guritno B. 1995. Analisis pertumbuhan tanaman. Yogyakarta (ID): Gadjah Mada University Press. 412 hal.

Wawan Aep. 2006. Budidaya tanaman kedelai (Glycine max). Fakultas Pertanian Unversitas Padjajaran.

Yasemin. 2005. The effect of drought on plant and tolerance mechanisms. G.U. J Sci 18(4): 723-740. 